Document downloaded from:

http://hdl.handle.net/10251/85107

This paper must be cited as:

Ullah, S.; Mollar García, MA.; Marí, B. (2016). Electrodeposition of CuGaSe2 and CuGaS2 thin films for photovoltaic applications. Journal of Solid State Electrochemistry. 20(8):22512257. doi:10.1007/s10008-016-3237-0.

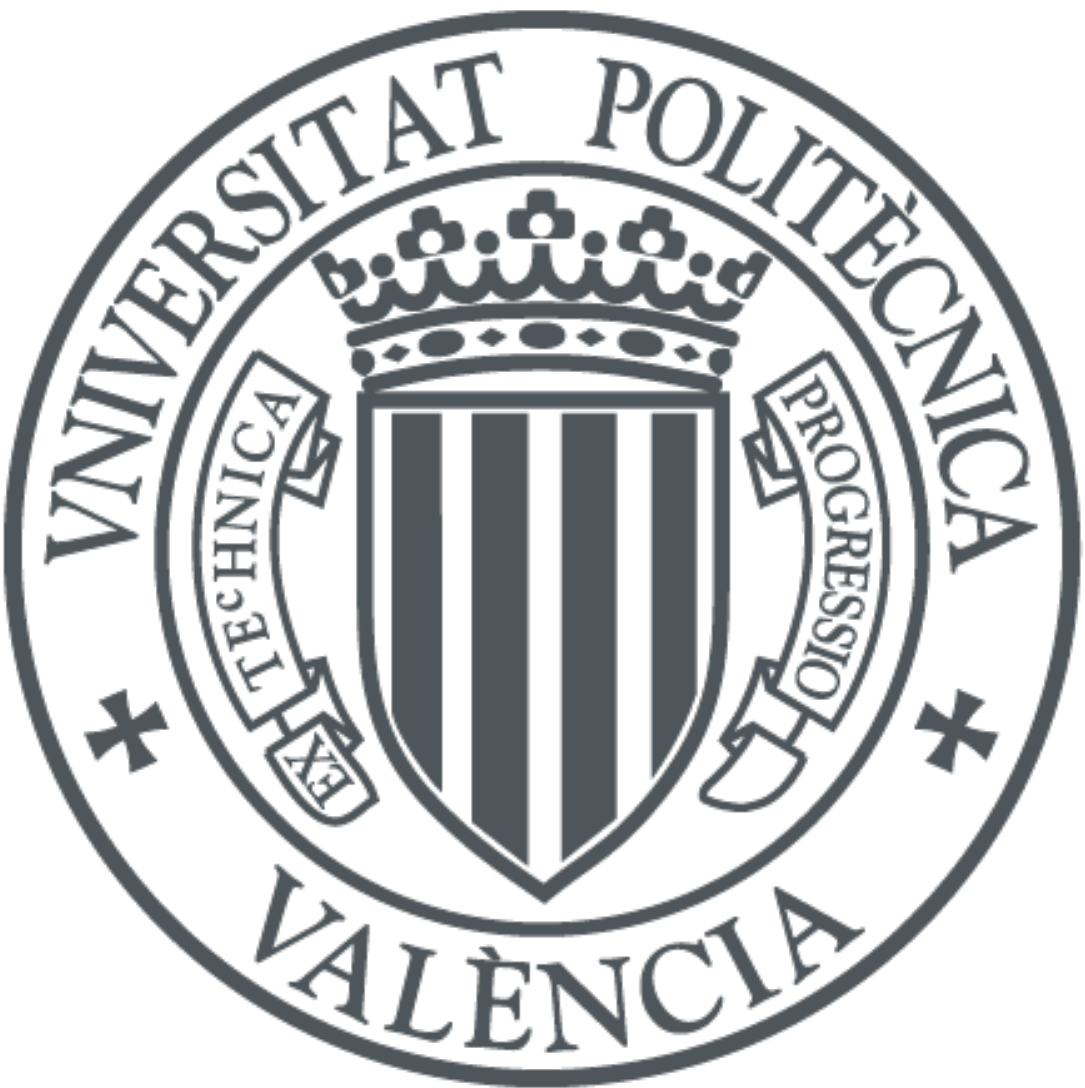

The final publication is available at

http://dx.doi.org/10.1007/s10008-016-3237-0

Copyright Springer Verlag (Germany)

Additional Information

The final publication is available at Springer via http://dx.doi.org/10.1007/s10008-016-32370 . 


\title{
Electrodeposition of $\mathrm{CuGaSe}_{2}$ and $\mathrm{CuGaS}_{2}$ Thin Films for Photovoltaic Applications
}

\author{
Shafi Ullah, Miguel Mollar, Bernabé Marí \\ Department de Física Aplicada-IDF, Universitat Politècnica de València, Camí de Vera s/n, 46022- \\ València, Spain \\ Corresponding author: Bernabé Marí (bmari@fis.upv.es) Tel +34 963877525 FAX +34 963877189
}

\begin{abstract}
$\mathrm{CuGaSe}_{2}$ and $\mathrm{CuGaS}_{2}$ polycrystalline thin film absorbers were prepared by one-step electrodeposition from an aqueous electrolyte containing $\mathrm{CuCl}_{2}, \mathrm{GaCl}_{3}$, and $\mathrm{H}_{2} \mathrm{SeO}_{3}$. The $\mathrm{pH}$ of the solution was adjusted to 2.3 by adding $\mathrm{HCl}$ and $\mathrm{KOH}$. Annealing improved crystallinity of $\mathrm{CuGaSe}_{2}$ and further annealing in sulfur atmosphere was required to obtain $\mathrm{CuGaS}_{2}$ layers. The morphology, topography, chemical composition and crystal structure of the deposited thin films were analysed by Scanning Electron Microscopy, Atomic Force Microscopy, Energy Dispersive Spectroscopy and X-Ray Diffraction, respectively. X-Ray diffraction showed that the as-deposited $\mathrm{CuGaSe}_{2}$ film exhibited poor crystallinity, but which improved dramatically when the layers were annealed in forming gas atmosphere for $40 \mathrm{~min}$. Subsequent sulfurization of $\mathrm{CuGaSe}_{2}$ films was performed at $400{ }^{\circ} \mathrm{C}$ for $10 \mathrm{~min}$ in presence of molecular sulfur and under forming gas atmosphere. The effect of sulfurization was the conversion of $\mathrm{CuGaSe}_{2}$ into $\mathrm{CuGaS}_{2}$. The formation of $\mathrm{CuGaS}_{2}$ thin films was evidenced by the shift observed in the X-Ray diffraction pattern and by the blue shift of the optical band gap. The bandgap of $\mathrm{CuGaSe}_{2}$ was found to be $1.66 \mathrm{eV}$, while for $\mathrm{CuGaS}_{2}$ it raised up to $2.2 \mathrm{eV}$. A broad intermediate absorption band associated to $\mathrm{Cr}$ and centred at $1.63 \mathrm{eV}$ was observed in $\mathrm{Cr}$-doped $\mathrm{CuGaS}_{2}$ films.
\end{abstract}

Keywords: Electrodeposition, Thin films, Chalcopyrite, Annealing, Selenization, Sulfurization, Intermediate Band.

\section{Acknowledgments}

This work was supported by Ministerio de Economía y Competitividad (ENE2013-46624-C4-4R) and Generalitat Valenciana (Prometeus 2014/044). One of the authors (S. Ullah) acknowledges the European Union (IDEAS-Call-3, Innovation and Design for Euro-Asian scholars) for its financial support. 


\section{Introduction}

Electrodeposition has considerable potential for application in the fabrication of low cost thin film solar cells. Chalcopyrite $\mathrm{Cu}(\mathrm{In}, \mathrm{Ga}) \mathrm{Se}_{2}$ solar cells are already commercially available but these devices can still be made less expensive by using low cost techniques such as electrodeposition.

Chalcopyrite $\mathrm{Cu}(\mathrm{In}, \mathrm{Ga}) \mathrm{Se}_{2}$ (CIGS) is one of the most important semiconductor materials that can be used to make low cost photovoltaic devices. The co-electrodeposition technique where $\mathrm{Cu}$ In-Ga-Se species are present in the same bath is one of the suitable techniques to prepare low cost thin films [1] because the deposition process is carried out at low temperatures, ambient pressure and does not require very sophisticated and expensive equipment.

For solar cell applications the bandgap of $\mathrm{Cu}(\mathrm{In}, \mathrm{Ga}) \mathrm{Se}_{2}$ thin film absorbers can be tuned in the $1.0-1.7 \mathrm{eV}$ range. Direct band gap semiconductors have several advantages over indirect band gap crystalline silicon. Indirect band gap semiconductors have lower absorption coefficients and then necessitate thick absorber layers to absorb enough light, which in turn may result in disadvantageous output in terms of electron diffusion length and recombination. On the other hand $\mathrm{Cu}(\mathrm{In}, \mathrm{Ga}) \mathrm{Se}_{2}$ thin films with a suitable Ga content hold the record for efficiency in photovoltaic thin films [2]. CIGS photovoltaic devices have reached a record solar cell efficiency of $20.4 \%$ [3]. They have a large optical absorption coefficient $\left(10^{5} \mathrm{~cm}^{-1}\right)$ and have yielded highest conversion efficiencies among thin film technologies at laboratory scale $[4,5,6]$.

Further, CIS-based cells have demonstrated excellent long-term stability with high radiation resistance. Efforts are currently being made to enhance the efficiency to the theoretical maximum $(30 \%)$ as well as to develop cheaper deposition strategies for the chalcopyrite absorber layer [7]. Nevertheless, there is still a window for further efficiency improvement for CIGS cells and modules. The second and most promising class is thin film solar cells; the market of thin film solar cells is expected to grow significantly in the coming years. The film technology has made solar cells more feasible to be employed as solar shingles, ie.as roof tiles. However, the efficiencies of these cells tend to be lower than those of silicon solar cells.

Various methods are used to prepare $\mathrm{Cu}(\mathrm{In}, \mathrm{Ga}) \mathrm{Se}_{2}$ thin films such as chemical bath deposition, spray pyrolysis, element co-evaporation, flash evaporation, electrodeposition etc. [8,9]. Compared with other methods, electrodeposition has several advantages, such as the high deposition speed and the possibility of producing large-area polycrystalline films at low cost.

$\mathrm{CuGaS}_{2}$ has a band gap of about $2.2 \mathrm{eV}$, which is too high to be used as absorber in photovoltaic devices based on one junction but it matches well to the optimal bandgap to host an intermediate 
band (IB) aimed to absorb photons with energies below the gap. In an IB material an electron can

be promoted from the valence band to the conduction band following two ways: a) absorbing a photon with energy higher than the bandgap of the materials, and b) through the absorption of two photons with energy below the gap. The absorption of one photon promotes one electron from the valence band to the partially filled intermediate band and then the electron is transferred from the intermediate band to the conduction band though the absorption of a second photon. This may allow a more efficient use of the solar spectrum in photovoltaic devices. Such devices will posses higher open circuit voltages due to a higher current to be the higher band gap energy of the absorbing material and higher photocurrents due to the absorption of sub-band gap photons resulting in an increase of the overall efficiency [10].

Recently, (Palacios et al) proposed that $\mathrm{CuGaS}_{2}$ materials doped with chrome can act as a suitable intermediate band absorber [11]. These theoretical calculations were based on first principles and demonstrated that $\mathrm{CuGaS}_{2}$ material doped with transition metals with partially filled bands (in particular chrome) is a suitable candidate to host an intermediate band and then promote electron-hole pairs using two photon absorption with sub-bandgap energies. According the reference [11] Cr substituting $\mathrm{Ga}$ in $\mathrm{CuGaS}_{2}$ chalcopyrite structures would generate an intermediate band.

Herein, we report the electrodeposition and characterization of $\mathrm{CuGaSe}_{2}$ thin films and subsequent conversion into $\mathrm{CuGaS}_{2}$ through a short process of thermal annealing in presence of sulfur. The replacement of Se by $\mathrm{S}$ is inferred by the changes observed in the related diffractograms and by the shift of the optical bandgap from $1.66 \mathrm{eV}$ for $\mathrm{CuGaSe}_{2}$ to $2.20 \mathrm{eV}$ for $\mathrm{CuGaS}_{2}$. Crdoping were achieved by adding $\mathrm{Cr}^{3+}$ ions into the starting electrolyte. The effectiveness of $\mathrm{Cr}$ doping was inferred from the presence of $\mathrm{Cr}$ in $\mathrm{CuGaS}_{2}$ layers and the optical detection of a subbandgap absorption band. The results of the investigation of their compositional, morphological, structural and optical properties are presented in detail.

\section{Experimental details}

Electrodeposition was carried out potentiostatically in a three-electrode cell configuration where the reference electrode was $\mathrm{Ag} / \mathrm{AgCl}$, the counter electrode a platinum wire, and the working electrode were $1-\mu \mathrm{m}$-thick Mo-coated glass and ITO-coated substrates. All substrates were ultrasonically cleaned with acetone, rinsed with deionized water and subsequently dried. The films were obtained in a vertical cell in which the working and the counter electrode were suspended vertically from the top of the cell. 
Before deposition, the solution was deaerated by argon bubbling and stirred up for 20 minutes.

The applied potential was fixed at $-0.6 \mathrm{~V}$ versus the reference electrode $(\mathrm{Ag} / \mathrm{AgCl})$ and the electrodeposition period was $30 \mathrm{~min}$. The temperature was maintained at $25^{\circ} \mathrm{C}$ without stirring the solution during the deposition. All electrodeposition procedures were performed using Autolab PGSTAT 302N.

$\mathrm{CuGaSe}_{2}$ layers were electrodeposited from an electrolyte solution containing of $2 \mathrm{mmol} \mathrm{L}^{-1}$ $\mathrm{CuCl}_{2}, 4 \mathrm{mmol} \mathrm{L}^{-1} \mathrm{H}_{2} \mathrm{SeO}_{3}, 10 \mathrm{mmol} \mathrm{L}^{-1} \mathrm{GaCl}_{3}, 50 \mathrm{mmol} \mathrm{L}^{-1} \mathrm{KSCN}, 100 \mathrm{mmol} \mathrm{L}^{-1} \mathrm{NH}_{4} \mathrm{Cl}$ and 300 mmol $\mathrm{L}^{-1} \mathrm{LiCl}$. The $\mathrm{pH}$ was adjusted to 2.3 by adding potassium hydroxide $(\mathrm{KOH})$ and hydrochloric acid $(\mathrm{HCl})$. Addition of $\mathrm{LiCl}$ as supporting electrolyte provides better stability of the electrodeposition bath solution and also improves the quality of the deposited layers. After electrodeposition, the as-deposited films were annealed at $450{ }^{\circ} \mathrm{C}$ under forming gas $\left(10 \% \mathrm{H}_{2}\right.$ in $\left.\mathrm{N}_{2}\right)$ atmosphere with a pressure of $10^{-2}$ bar to improve the crystallinity of the $\mathrm{CuGaSe}_{2}$ films.

$\mathrm{CuGaS}_{2}$ layers were obtained by performing a subsequent sulfurization process to electrodeposited $\mathrm{CuGaSe}_{2}$ layers. The sulfurization process was carried out by annealing the asdeposited $\mathrm{CuGaSe}_{2}$ thin films in a graphite box. $100 \mathrm{mg}$ of molecular sulfur were added to the graphite box, which was placed in a quartz tube kept in forming gas atmosphere at a pressure of $10^{-2}$ bar. The quartz tube was located inside a cylindrical oven at a temperature of $400{ }^{\circ} \mathrm{C}$ for 10 minutes.

For doping purposes $\mathrm{Cr}^{3+}$ ions were added to the electrolyte described above. $150 \mathrm{mMol} \mathrm{L}^{-1}$ of $\mathrm{Cr}\left(\mathrm{ClO}_{4}\right)_{3}$ were dissolved in $40 \mathrm{ml}$ of the electrolyte aqueous solution. In this case the $\mathrm{pH}$ of the final solution was adjusted between 2.3 and 2.4 by using concentrated $\mathrm{HCl}$. Electrodeposition produces $\mathrm{Cr}$-doped $\mathrm{CuGaSe}_{2}$ films and these films were subsequently sulfurized following the sulfurization procedure described before.

The crystal structure of $\mathrm{CuGaSe}_{2}$ and $\mathrm{CuGaS}_{2}$ thin films were investigated by X-Ray Diffraction (XRD) using a Rigaku Ultima IV diffractometer in the Bragg-Bentano configuration using $\mathrm{CuK} \alpha$ radiation $(\lambda=1.54060 \AA)$. Chemical composition, surface morphology, and topography were characterized using energy dispersive spectroscopy (EDS), Field Emission Scanning Electron Microscopy (FESEM), a Zeiss ULTRA 55 model equipped with an In-Lens SE detector and Atomic Force Microscopy, AFM, Bruker Multimode 8 AFM Nanoscope V controller, respectively.

\section{Results and discussion}

The redox reaction of different elements of $\mathrm{CuGaSe}_{2}$ in the electrolytic bath were analysed by cyclic voltammetry. Voltammograms were recorded at $100 \mathrm{mV} \mathrm{s}^{-1}$ and the potential was scanned first in the negative direction. $0.3 \mathrm{~mol} \mathrm{~L}^{-1} \mathrm{LiCl}$ was added as supporting electrolyte in order to avoid 
the effect of different ionic strengths and the $\mathrm{pH}$ was adjusted to 2.3. A Mo-coated glass substrate was used as working electrode.

Figure 1 shows the cyclic voltammetry carried out in a three-electrode electrochemical cell at a scan rate of $100 \mathrm{mV} \mathrm{s}^{-1}$. The dashed black curve represents the cyclic voltammetry for the blank solution. Showing a peak at $-0.81 \mathrm{~V}$ attributed to the reduction of $\mathrm{H}^{+}$to $\mathrm{H}_{2}$. The red curve is the cyclic voltammetry for a copper-selenium solution. It shows a reduction peak at $-0.69 \mathrm{~V}$ attributed to the formation of copper selenides. The blue curve is the cyclic voltammetry of the former solution after addition of $\mathrm{Ga}^{3+}$. The addition of $\mathrm{Ga}^{3+}$ shifts the former peak from $-0.69 \mathrm{~V}$ until $-0.57 \mathrm{~V}(+0.12 \mathrm{~V})$ and it is attributed to $\mathrm{Ga}_{2} \mathrm{Se}_{3}$ (eq. 1). Then, the generated $\mathrm{Ga}_{2} \mathrm{Se}_{3}$ is assimilated into copper selenides and, according to ref. [12], is rapidly transformed into copper gallium diselenide (eq. 2).

$$
\begin{gathered}
3 \mathrm{H}_{2} \mathrm{Se}+2 \mathrm{Ga}^{3+} \leftarrow \rightarrow \mathrm{Ga}_{2} \mathrm{Se}_{3}+6 \mathrm{H}^{+} \\
\mathrm{Cu}_{2} \mathrm{Se}+\mathrm{Ga}_{2} \mathrm{Se}_{3} \leftarrow \rightarrow 2 \mathrm{CuGaSe}_{2}
\end{gathered}
$$

Figure 2 shows the XRD patterns of $\mathrm{CuGaSe}_{2}$ and $\mathrm{CuGaS}_{2}$ thin films at their different preparation stages: (a) as deposited $\mathrm{CuGaSe}_{2}$, (b) $\mathrm{CuGaSe}_{2}$ thin films annealed at $450{ }^{\circ} \mathrm{C}$ in forming gas atmosphere and (c) sulfurized $\mathrm{CuGaSe}_{2}$ thin films annealed for 10 minutes $450{ }^{\circ} \mathrm{C}$.

The XRD pattern of the as-deposited sample, Fig. 2 (a), does not show visible peaks except for the Mo substrate, meaning poor crystallinity of the as-deposited films. After thermal annealing, an improvement in the sharpness and intensity of the diffraction peaks is observed due to the crystallization and grain growth.

Figure 2 (b) displays the X-ray diffraction pattern of the annealed $\mathrm{CuGaSe}_{2}$ sample. This diffractogram matches well with the tetragonal crystal system JCPDS No. 075-0104 pattern, corresponding to $\mathrm{CuGaSe}_{2}$. The major peaks are located at $27.9^{\circ}, 46.2^{\circ}$ and $54.4^{\circ}$, respectively, corresponding to (1 112$)$, (2 $\left.\begin{array}{lll}2 & 2 & 0\end{array}\right) /\left(\begin{array}{lll}2 & 0 & 4\end{array}\right)$ and (3 112$) /\left(\begin{array}{lll}1 & 1 & 2\end{array}\right)$ diffraction planes.

The sulfurization process of the as-deposited $\mathrm{CuGaSe}_{2}$ films takes place after a short annealing time in presence of molecular sulfur, resulting in the formation of the $\mathrm{CuGaS}_{2}$ chalcopyrite phase as revealed by the XRD pattern of sulfurized films.

Fig. 2 (c) presents the X-ray diffraction pattern of a sulfurized $\mathrm{CuGaSe}_{2}$ sample. The XRD peaks shift to higher angles with the sulfurization process. The main XRD peak corresponding to $\left(\begin{array}{lll}1 & 1 & 2\end{array}\right)$ diffraction peaks shifts from 27.9 to 29.0 degrees. Further, the peaks corresponding to (2 20$)$ and (2 $\left.\begin{array}{ll}0 & 4\end{array}\right)$ and $\left(\begin{array}{lll}3 & 1 & 2\end{array}\right)$ and $\left(\begin{array}{lll}1 & 1 & 6\end{array}\right)$ diffraction planes observed for annealed $\mathrm{CuGaSe}_{2}$ films also shift to higher angles for sulfurized films. This XRD peaks match well with the JCPDS No. 75-0103 pattern 
corresponding to $\mathrm{CuGaS}_{2}$ films. This diffraction pattern confirms that, after sulfurization, Se atoms have been replaced by $\mathrm{S}$ atoms, and consequently $\mathrm{CuGaSe}_{2}$ thin films have been transformed into $\mathrm{CuGaS}_{2}[13,14,15]$.

Both $\mathrm{CuGaSe}_{2}$ and $\mathrm{CuGaS}_{2}$ films exhibit a tetragonal crystalline structure. The XRD patterns of $\mathrm{CuGaSe}_{2}$ and $\mathrm{CuGaS}_{2}$ thin films have a highly crystalline structure, offering the possibility of being used for photovoltaic devices with high conversion efficiency [16].

The crystallite size of electrodeposited and annealed $\mathrm{CuGaSe}_{2}$ and sulfurized $\mathrm{CuGaS}_{2}$ thin films was calculated applying the standard Debye-Scherrer formula to the $\left(\begin{array}{lll}1 & 1 & 2\end{array}\right)$ diffraction peak:

$$
D(\AA)=K \lambda / \beta \cos \theta
$$

Where $\beta$ is the full width at half maximum (FWHM), $\lambda$ is the X-ray wavelength having a value of $1.5418 \AA(\mathrm{CuK \alpha}), K$ is a proportionality constant ( $K=0.9$ was used) and $\theta$ is the Bragg angle at the centre of the peak. The crystallite size $D$ is the size of the crystal in the perpendicular direction to the reflecting planes [17]. It is noteworthy that the crystallite size is slightly bigger for $\mathrm{CuGaS}_{2}$ than for $\mathrm{CuGaSe}_{2}$ films, i.e. when Se is replaced by S, the crystallinity of thin films improves. Table I summarizes the position, FWHM and crystallite sizes for the main $\left(\begin{array}{lll}1 & 1 & 2\end{array}\right)$ XRD peak for both selenized $\left(\mathrm{CuGaSe}_{2}\right)$ and sulfurized $\left(\mathrm{CuGaS}_{2}\right)$ samples.

Figure 3 shows the SEM images of the surface morphology for as-deposited, annealed and sulfurized $\mathrm{CuGaSe}_{2}$ thin films on Mo-coated substrates. Clusters of about $200 \mathrm{~nm}$ made by aggregation of smaller grains can be observed for as-deposited $\mathrm{CuGaSe}_{2}$ films in Figure 3 (a). Figure 3 (b) and (c) show the SEM images for the annealed $\mathrm{CuGaSe}_{2}$ and sulfurized $\mathrm{CuGaS}_{2}$ thin films. An aggregation process of grains seems to have occurred and the observed grains are now larger than $400 \mathrm{~nm}$ in both cases. The coalescence of grains increases with either annealing processes. These results are compatible with the XRD results. According to the XRD analysis, the as-deposited samples have low crystallinity as no diffraction peaks are observed. However, after the two annealing processes mentioned here the films the X-Ray diffraction peaks appear, which means that the films became crystalline after annealing. According to SEM measurements the thickness of both selenized $\left(\mathrm{CuGaSe}_{2}\right)$ and sulfurized $\left(\mathrm{CuGaS}_{2}\right)$ films is about $1 \mu \mathrm{m}$.

The surface morphology and the roughness of the $\mathrm{CuGaSe}_{2}$ and $\mathrm{CuGaS}_{2}$ as analysed by Atomic Force Microscope is presented in Figure 4. It can be seen that small grains are grouped to form by cauliflower-like clusters. According to Atomic Force Microscopy, the roughness of the film increases through annealing, for this reason the density of grain boundaries should be low (big 
grains) to reduce the recombination rate and improve the quality of the films and cell performance, which is favourable for solar cell applications as a rough surface will trap more light [18].

Table II shows the characterization results performed by Atomic Force Microscopy. A linear relationship between the roughness and the grain size for all studied films was observed, when the roughness increases, the grain size also increases. The as-deposited $\mathrm{CuGaSe}_{2}$ roughness is $234 \mathrm{~nm}$ and the grain size is $160 \mathrm{~nm}$. After annealing the roughness of the films increases from 234 to 336 $\mathrm{nm}$ and the grain size also increases 2 times from 160 to $334 \mathrm{~nm}$. The sulfurization process also results in higher values for the roughness increasing to $422 \mathrm{~nm}$, and for the grain size grows up to $573 \mathrm{~nm}$. The increase of the grain size observed after the annealing process is a consequence of the recrystallization process occurring during the annealing process and agrees with the increase of crystallite sizes observed by XRD.

Energy Dispersive X-ray Spectroscopy was used to determine the composition of deposited $\mathrm{CuGaSe}_{2}$ and $\mathrm{CuGaS}_{2}$ films. Figures 5 a) and b) show the EDS spectra of annealed $\mathrm{CuGaSe}_{2}$ and $\mathrm{CuGaSe}_{2}$ films doped with chrome. Main X-ray peaks belong to $\mathrm{Cu}, \mathrm{Ga}$, Se and Mo, which come from the substrate. In Cr-doped $\mathrm{CuGaSe}_{2}$ films two lines located at 5.5 and $6.0 \mathrm{keV}$, respectively, support the presence of chrome in these samples. After sulfurization the lines related to Se are reduced, the conversion of selenium into sulfur after the sulfurization process becomes evident. Only a residual part of selenium (lower that 1\%) remains after 10-minutes sulfurization.

The quantification of the EDS analysis is shown in Table III. The measured $\mathrm{Se} /(\mathrm{Cu}+\mathrm{Ga})$ ratio for as-deposited $\mathrm{CuGaSe}_{2}$ films is 1.02 , while for selenized $\mathrm{CuGaSe}_{2}$ films it is 1.07 , meaning that both samples have a slight deficit of Ga. After sulfurization, most of the selenium is substituted by sulfur and only $0.9 \%$ of Se remains. The $(\mathrm{S}+\mathrm{Se}) /(\mathrm{Cu}+\mathrm{Ga})$ is practically the same. Thus, the results obtained show that the samples are stoichiometric.

The content of chrome in doped films always remains between 1 and $2 \%$, irrespective of the amount of $\mathrm{Cr}^{3+}$ added to the starting electrolyte. That means that the ratio $\mathrm{Cr}$ :Ga ranges from 4 to $8 \%$. It is noteworthy that the sensitivity of EDS measurements is estimated to be about $1 \%$.

\section{Optical analysis}

The optical transmittance and absorption spectra were recorded for $\mathrm{CuGaSe}_{2}$ and $\mathrm{CuGaS}_{2}$ films electrodeposited on a conductive transparent ITO substrate in order to evaluate the optical energy bandgap (Eg). In fact, the fundamental absorption edge in semiconductor material can be used to determine the energy bandgap according to the relationship, 


$$
(\alpha h v)^{2}=\mathrm{A}(h v-\mathrm{E} g)^{\mathbf{n}} / h v
$$

where $\alpha$ is the absorption coefficient of the material, hv is the photon energy $(\mathrm{eV}), v$ is the photon frequency, $h$ is the Plank's constant, Eg is the optical bandgap of the material, A is a constant which is related to the effective masses of both electron and holes in the bands and $\mathrm{n}$ being a constant associated with the nature of the optical transition in the material (direct allowed, direct forbidden, indirect allowed or indirect forbidden transitions). For a direct allowed transition or direct bandgap such as $\mathrm{CuGaSe}_{2}$ and $\mathrm{CuGaS}_{2}, \mathrm{n}$ assumes the value of $1 / 2$ and then the plot of $(\alpha h v)^{2}$ versus photon energy $(h v)$ forms a straight line whose intercept with the $(\alpha h v)^{2}=0$ axis yields the value of the energy bandgap $(\mathrm{Eg})[19,20]$.

Figure 6 displays $(\alpha h v)^{2}$ versus photon energy hv for $\mathrm{CuGaSe}_{2}$ and $\mathrm{CuGaS}_{2}$ thin films. As can be seen, the intercept with the $(\alpha h v)^{2}=0$ axis yields 1.66 and $2.20 \mathrm{eV}$ for $\mathrm{CuGaSe}_{2}$ and $\mathrm{CuGaS}_{2}$ thin films, respectively. These values are very close to those reported for $\mathrm{CuGaSe}_{2}$ and $\mathrm{CuGaS}_{2}$, respectively. The shift of the optical bandgap to higher energies confirms again the transformation of $\mathrm{CuGaSe}_{2}$ to $\mathrm{CuGaS}_{2}$ as a consequence of the above mentioned 10 minutes sulfurization process.

Figure 7 compares the normalized absorbance for $\mathrm{CuGaSe}_{2}, \mathrm{CuGaS}_{2}$ and $\mathrm{CuGaS}_{2}: \mathrm{Cr}$ thin films related to the wavelength. The blue shift of the onset of the absorbance (or bandgap) in $\mathrm{CuGaS}_{2}$ films with respect to $\mathrm{CuGaSe}_{2}$ films is evident. However, the absorbance for $\mathrm{CuGaS}_{2}: \mathrm{Cr}$ films exhibits an additional characteristic with respect to undoped $\mathrm{CuGaS}_{2}$ films, namely an absorption band below the bandgap. The broad absorption band observed for $\mathrm{CuGaS}_{2}: \mathrm{Cr}$ is centred at $760 \mathrm{~nm}$ $(1.63 \mathrm{eV})$ and can be assigned to a sub-band absorption band related to Cr-doping. According to theoretical studies, $\mathrm{Ga}^{3+}$ substitution by transition metals into $\mathrm{CuGaS}_{2}$ chalcopyrite structures would give rise to a partially filled absorption band, which will favour the promotion of electrons from the valence band to the absorption band through a two-photon absorption process [21].

Among the several strategies proposed for thin film solar cells the concept of intermediate-band solar cells has caught a great deal of attention in recent. The inserted intermediate band gap energy position neither overlapps the valence band nor the conduction band (CB), the IB not only absorbs one photon of higher energy than the band gap width $\left(\mathrm{E}_{\mathrm{g}}\right)$ but also promotes the absorption of two lower energy photons, which, respectively, promote one electron from the valence band (VB) to the IB and from the IB to the CB [22]. This intermediate band associated to Cr-doping in $\mathrm{CuGaS}_{2}$ may allow a higher current to be obtained at the voltage corresponding to the energy gap value; increasing the overall efficiency of thin film solar cells. 


\section{Conclusion}

$\mathrm{CuGaSe}_{2}$ and $\mathrm{CuGaS}_{2}$ thin films suitable for solar cells were successfully prepared by electrodeposition on ITO and Mo-coated glass substrates. $\mathrm{CuGaSe}_{2}$ thin films were deposited from an aqueous electrolyte containing the suitable precursors. Annealing in Se atmosphere at $450{ }^{\circ} \mathrm{C}$ dramatically improves the crystallinity of $\mathrm{CuGaSe}_{2}$ films. $\mathrm{CuGaS}_{2}$ films were obtained by subsequent sulfurization at $450{ }^{\circ} \mathrm{C}$ in presence of molecular sulfur of as-deposited $\mathrm{CuGaSe} \mathrm{S}_{2}$ layers. Crystallite sizes of about 43-48 $\mathrm{nm}$ were obtained for both thermally treated $\mathrm{CuGaSe}_{2}$ and $\mathrm{CuGaS}_{2}$ films.

When annealing in sulfur atmosphere two processes take place, conversion of Se in to S leading the formation of $\mathrm{CuGaS}_{2}$ thin films and improvement of its crystallinity. The replacement of Se by $\mathrm{S}$ is inferred by the changes observed in the $\mathrm{X}$ ray diffractogram and by the shift of the optical bandgap from $1.66 \mathrm{eV}$ for $\mathrm{CuGaSe}_{2}$ to $2.20 \mathrm{eV}$ for $\mathrm{CuGaS}_{2}$.

Cr-doping was achieved by adding $\mathrm{Cr}^{3+}$ to the starting electrolyte. The effectiveness of Crdoping was inferred from the presence of $\mathrm{Cr}$ in $\mathrm{CuGaS}_{2}$ layers and the optical detection of a subbandgap absorption band. According to EDS measurements the amount of Ga atoms substituted by Cr ranges from 4 to $8 \%$. Further, an intermediate absorption band centred at about $1.63 \mathrm{eV}$ above the valence band is observed in $\mathrm{CuGaS}_{2}: \mathrm{Cr}$ films. The intermediate band in $\mathrm{CuGaS}_{2}: \mathrm{Cr}$ films would allow the absorption of photons with energy higher than the bandgap $\left(E_{g}\right)$ and also the absorption of two lower energy photons, which promote electrons from the VB to the IB and from the IB to the $\mathrm{CB}$, respectively. Therefore this intermediate band associated to $\mathrm{Cr}$-doping in $\mathrm{CuGaS}_{2}$ may allow a higher current to be obtained at the voltage corresponding to the energy gap value, so increasing the overall efficiency of the solar cell.

\section{References}

[1] Calixto ME, Sebastian PJ, Bhattacharya RN, Noufi (1999) Sol Energ Mat Sol C 59:75-84

[2] Mandati S, Sarada BV, Dey SR, Joshi SV (2015) J Power Sources 273:149-157

[3] Jacobsson TJ, Fjällström V, Edoff M, Edvinsson T (2015) Sol Energ Mat Sol C 134:185-193

[4] Carrete A, Placidi M, Shavel A, Pérez Rodríguez A, Cabot A (2015) Phys Stat Sol (a) 212:67-71

[5] Saji VS, Choi Ik-Ho, Lee CW (2011) Sol Energy 86:2666-2678

[6] Park MG, Ahn SJ, Yun JH, Gwak J, Cho A, Ahn SK, Shin K, Nam D, Cheong H, Yoon K (2012) J Alloy Compd 513: 68-74

[7] Saji VS, Lee SM, Lee CW (2011) Journal of the Korean Electrochemical Society 14:61-70 
[8] Donglin X, Jangzhuang L, Man X, Xiujian Z (2008) Journal of Non-Crystalline Solids $354: 1447-1450$

[9] J. Araujo, R. Ortíz , A. López-Rivera, J. M. Ortega, M. Montilla, D. Alarcón (2007) J Solid

State Electroch Volume 11, Issue 3, pp 407-412

[10] Palacios P, Sanchez K, Conesa JC, Fernandez JJ, Wahnon P (2007) Phys Stat Sol A 203:13951401

[11] Palacios P, Sanchez K, Conesa JC, Wahnon P (2006) Thin Solid Films 515:6280-6284

[12] Lee H, Lee J-H, Hwang Y-H, Kim Y, (2014) Current Applied Physics 14:18-22

[13] Kim D, Kwon Y, Lee D, Yoon S, Lee S, Yoo B (2015) Journal of Electrochemical Society 162:D36-D41

[14] Hou WW, Bob B, Li S, Yang Y (2009) Thin Solid Films 517:6853-6856

[15] Lee J, Lee W, Shrestha NK, Lee DY, Lim I, Kang SH, Nah YC, Lee SH, Yi W, Han SH (2014) Mater Chem Phys 144:49-54

[16] Yang JY, Lee D, Huh K, Jung SJ, Lee JW, Lee HC, Baek DH, Kim BJ, Kim D, Nam J, Kim GY, Jo W (2015) RSC Adv 5:40719-407257

[17] Sall T, Nafidi A, Marí B, Mollar M, Hartiti B, Fahoume M (2014) J Semicond 35: 06300210630025

[18] Lee JH, Song WC, Yi JS, Joonyang K, Han WD, Hawang J (2003) Thin Solid Films 431-432: 349-353

[19] Prabukanthan P, Dhanasekaran R (2007) Cryst Growth Des 7:618-623

[20] Guillemoles JF, Cowache P, Lusson A, Fezzaa K, Boisivon F, Vedel J, Lincot D (1996) J Appl Phys 79:7293-7302

[21] Aguilera I, Palacios P, Wahon P (2010) Sol Energ Mat Sol C 94:1903-1906

[22] Palacios P, Aguilera I, Wahnón P, Conesa JC ( 2008) J Phys Chem C 112: 9525-9529 


\section{FIGURE CAPTIONS}

Figure 1. Cyclic voltammogram of a Mo-coated electrode in three precursor electrolytes: blank solution (dashed line), $4 \times 10^{-3} \mathrm{~mol} \mathrm{~L}^{-1} \mathrm{Se}^{4+}, 2 \times 10^{-3} \mathrm{~mol} \mathrm{~L}^{-1} \mathrm{Cu}^{2+}$ (red line) and (blue line). $1 \times 10^{-2} \mathrm{~mol}$ $\mathrm{L}^{-1} \mathrm{Ga}^{3+}$. Each solution contains $0.3 \mathrm{~mol} \mathrm{~L}^{-1} \mathrm{LiCl}_{2}$ as supporting electrolyte and the $\mathrm{pH}$ was adjusted to 2.3. The scan rate was $100 \mathrm{mV} \mathrm{s}^{-1}$.

Figure 2. XRD patterns of $\mathrm{CuGaSe}_{2}$ and $\mathrm{CuGaS}_{2}$ films: (a) As deposited $\mathrm{CuGaSe}_{2}$ (b) After annealing at $450{ }^{\circ} \mathrm{C}$ in $\mathrm{Ar}$ atmosphere and (c) After sulfurization in molecular Sulphur for 10 minutes at $400^{\circ} \mathrm{C}$.

Figure 3. SEM images of surface morphology of $\mathrm{CuGaSe}_{2}$ and $\mathrm{CuGaS}_{2}$ films deposited on Mo electrodes at -0.6 during 30 min: (a) as-deposited $\mathrm{CuGaSe}_{2}$, (b) $\mathrm{CuGaSe}_{2}$ annealed for 40 min at $450{ }^{\circ} \mathrm{C}$ in argon atmosphere, (c) $\mathrm{CuGaS}_{2}$ films obtained after sulfurization of electrodeposited $\mathrm{CuGaSe}_{2}$ films.

Figure 4. AFM micrograph of as-deposited $\mathrm{CuGaSe}_{2}$ layers (a) as deposited (b), annealed $\mathrm{CuGaSe}_{2}$ layers in vacuum and (c) sulfurized.

Figure 5. EDS spectrum for: a) annealed $\mathrm{CuGaSe}_{2}$ b) $\mathrm{CuGaSe}_{2}$ doped by $\mathrm{Cr}$ : and c) sulfurized $\mathrm{CuGaS}_{2}$ thin films.

Figure 6. Plot of $(\alpha h v)^{2}$ vs. Photon energy for $\mathrm{CuGaSe}_{2}$ and $\mathrm{CuGaS}_{2}$ thin films.

Figure 7. Comparison of the absorbance of $\mathrm{CuGaSe}_{2}, \mathrm{CuGaS}_{2}$ and $\mathrm{CuGaS}_{2}: \mathrm{Cr}$ thin films. The broad absorption band observed for $\mathrm{CuGaS}_{2}: \mathrm{Cr}$, centred at $760 \mathrm{~nm}$ is attributed to Cr-related intermediate band. 


\section{FIGURES}

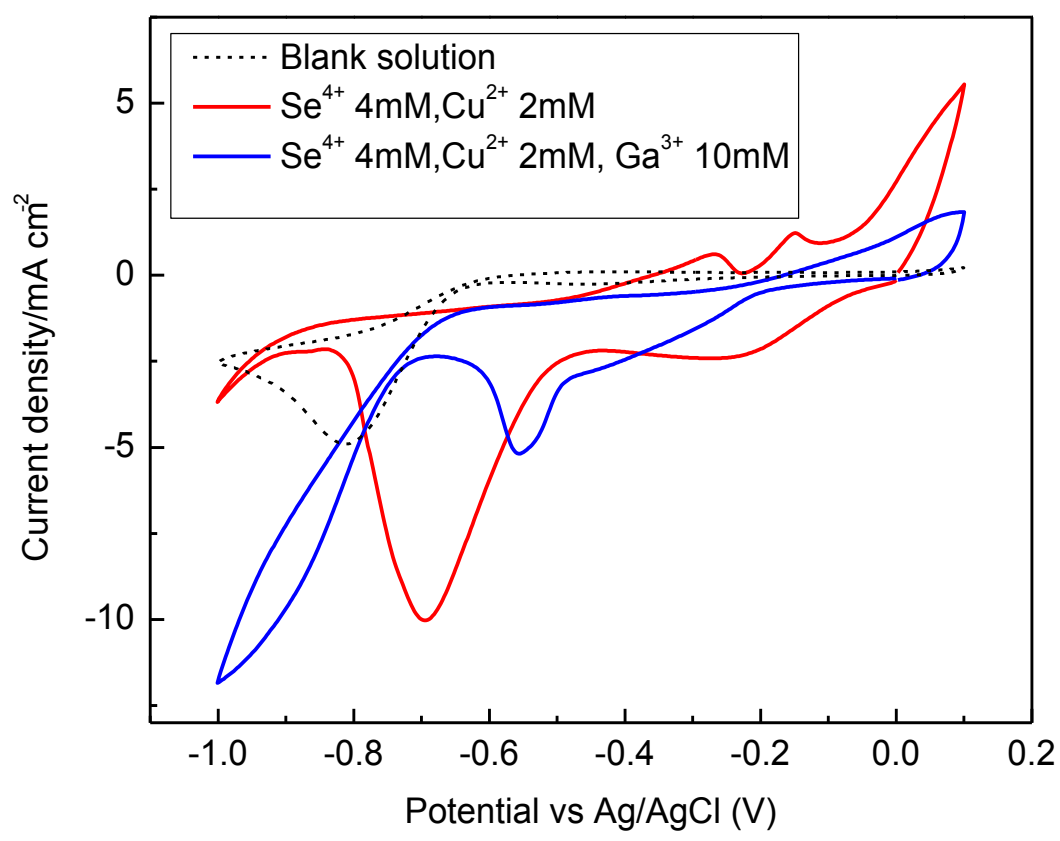

Figure 1. Cyclic voltammogram of a Mo-coated electrode in three precursor electrolytes: blank solution (dashed line), $4 \times 10^{-3} \mathrm{~mol} \mathrm{~L}-1 \mathrm{Se}^{4+}, 2 \times 10^{-3} \mathrm{~mol} \mathrm{~L}^{-1} \mathrm{Cu}^{2+}$ (red line) and (blue line). $1 \times 10^{-2}$ mol L-1 $\mathrm{Ga}^{3+}$. Each solution contains $0.3 \mathrm{~mol} \mathrm{~L}^{-1} \mathrm{LiCl}_{2}$ as supporting electrolyte and the $\mathrm{pH}$ was adjusted to 2.3. The sweep rate was $100 \mathrm{mV} \mathrm{s}^{-1}$.

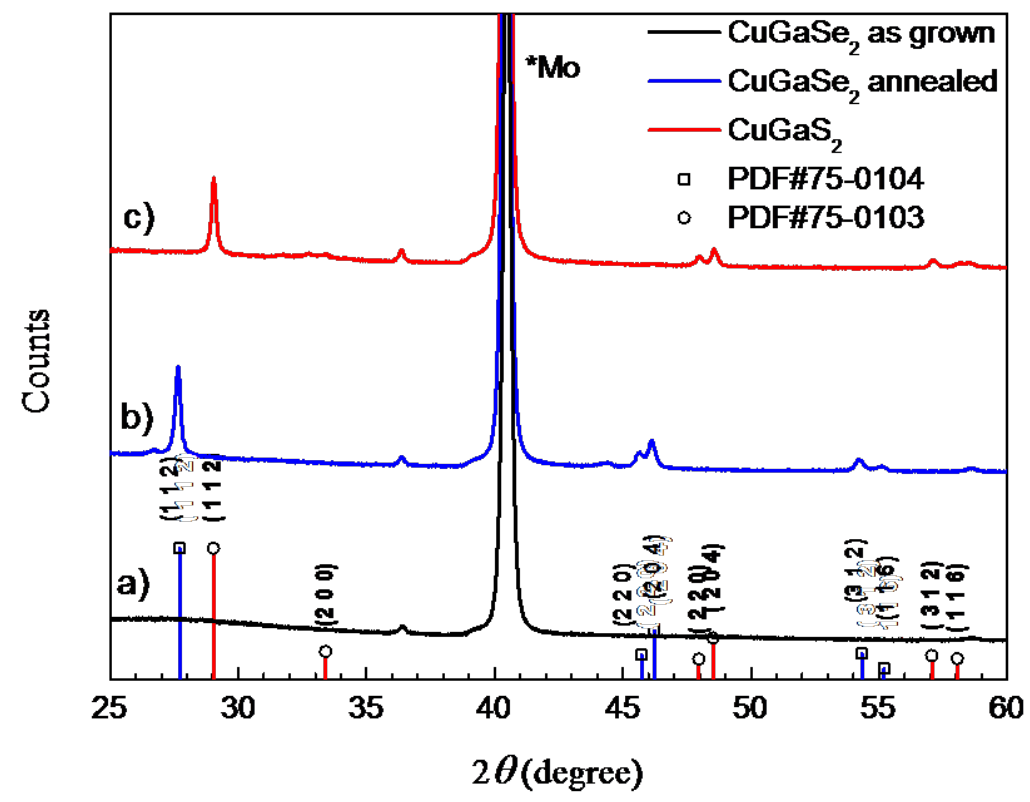

Figure 2. XRD patterns of $\mathrm{CuGaSe}_{2}$ and $\mathrm{CuGaS}_{2}$ films: (a) As deposited $\mathrm{CuGaSe}_{2}$ (b) After annealing at $450^{\circ} \mathrm{C}$ in forming gas atmosphere and (c) After sulfurization in molecular Sulphur for 10 minutes at $400{ }^{\circ} \mathrm{C}$. 

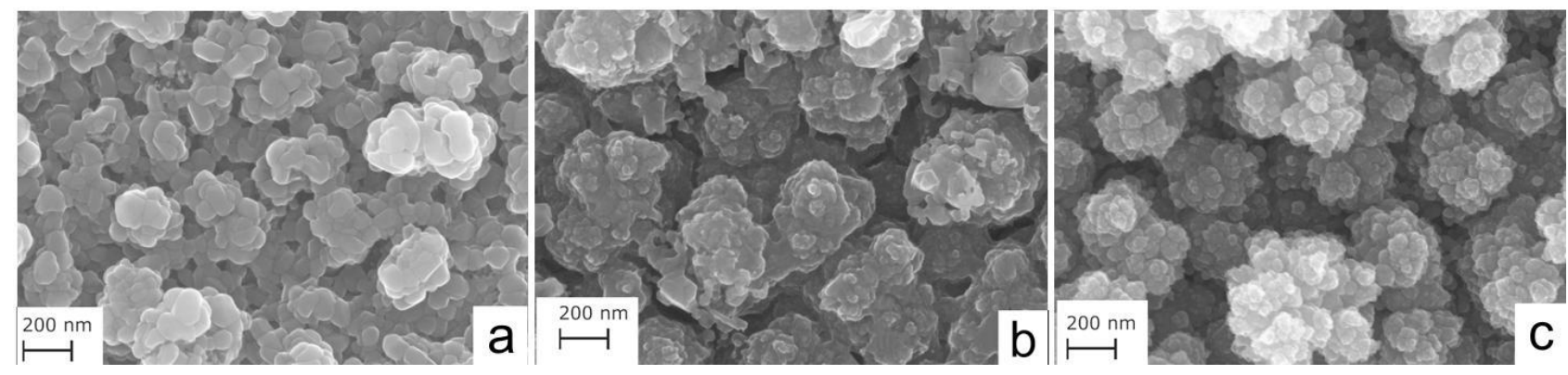

Figure 3. SEM images of surface morphology of $\mathrm{CuGaSe}_{2}$ and $\mathrm{CuGaS}_{2}$ films deposited on Mo electrodes at -0.6 during 30 min: (a) as-deposited $\mathrm{CuGaSe}_{2}$, (b) $\mathrm{CuGaSe}_{2}$ annealed for $40 \mathrm{~min}$ at $450{ }^{\circ} \mathrm{C}$ in forming gas atmosphere, (c) $\mathrm{CuGaS}_{2}$ films obtained after sulfurization of electrodeposited $\mathrm{CuGaSe}_{2}$ films.
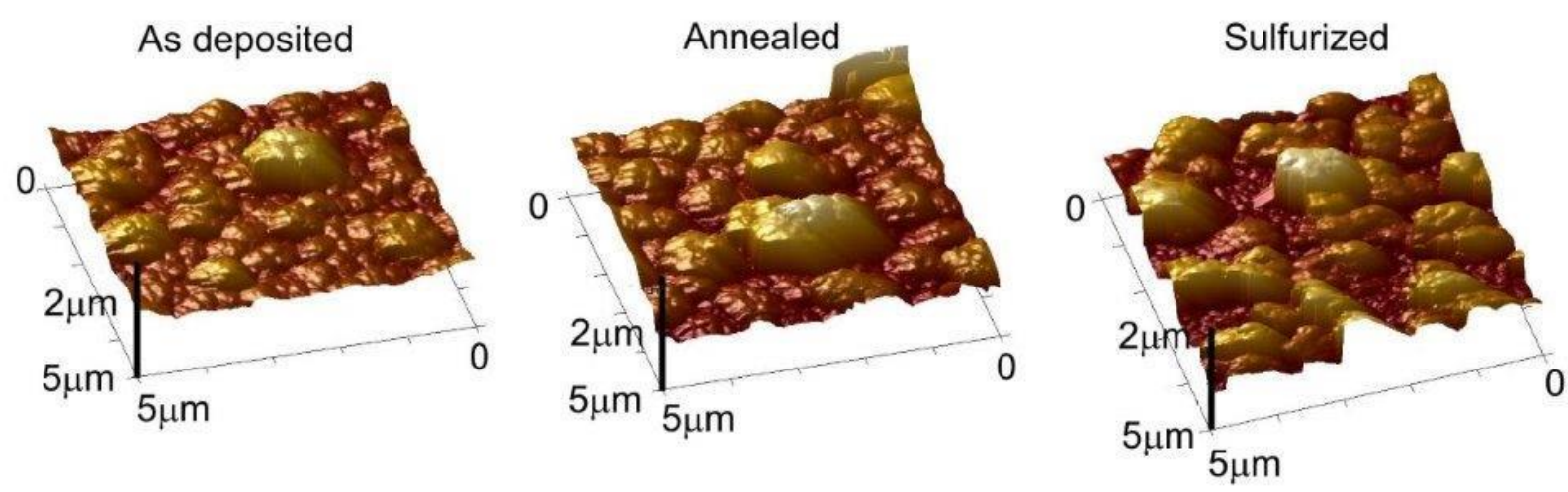

Figure 4. AFM micrograph of as-deposited $\mathrm{CuGaSe}_{2}$ layers (a) as deposited (b), annealed in selenium and (c) sulfurized. 


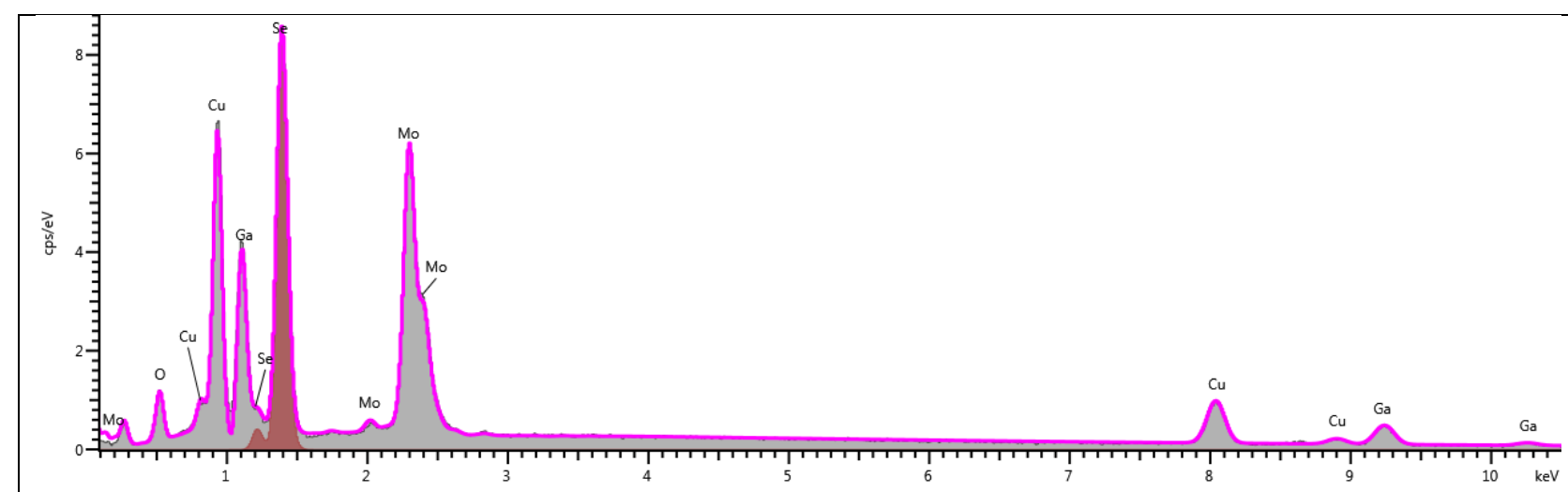

(a)

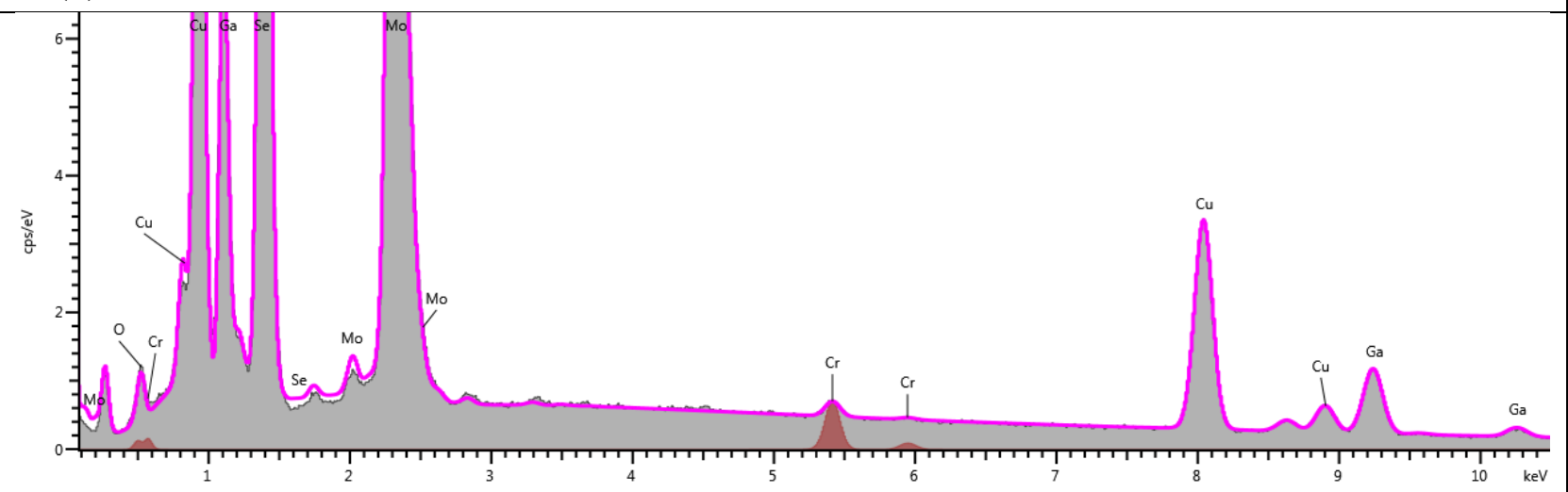

(b)

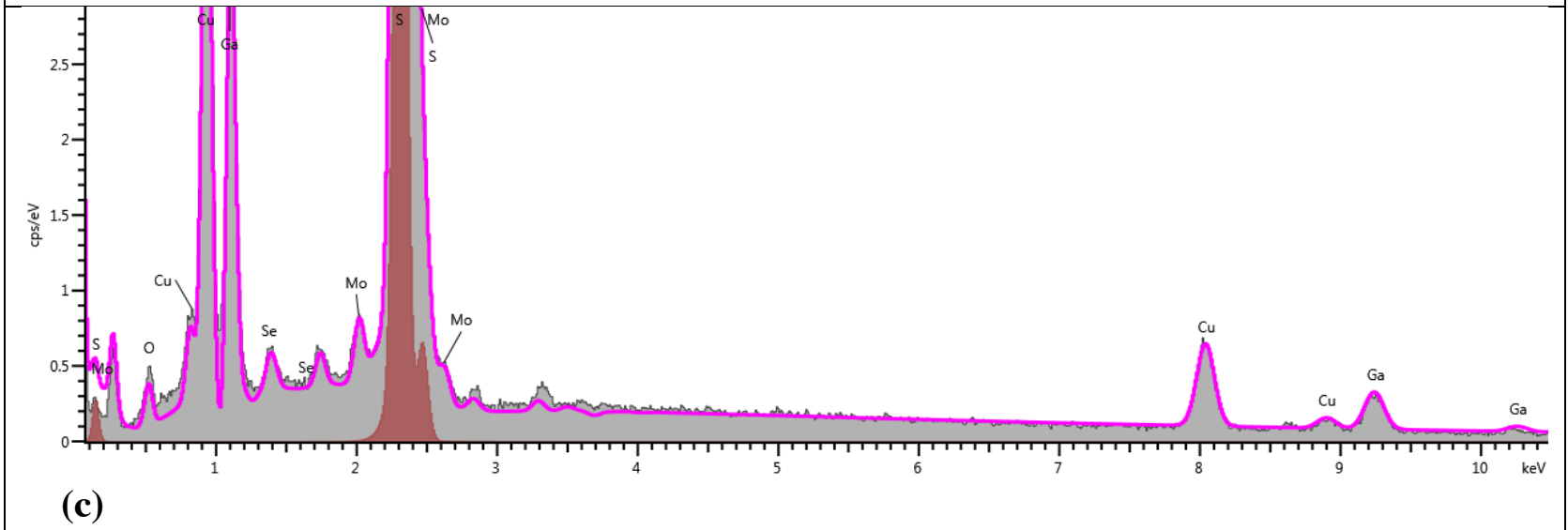

Figure 5. EDS spectrum for: a) annealed $\mathrm{CuGaSe}_{2}$ b) $\mathrm{CuGaSe}_{2}$ doped by $\mathrm{Cr}$ : and c) sulfurized $\mathrm{CuGaS}_{2}$ thin films. 


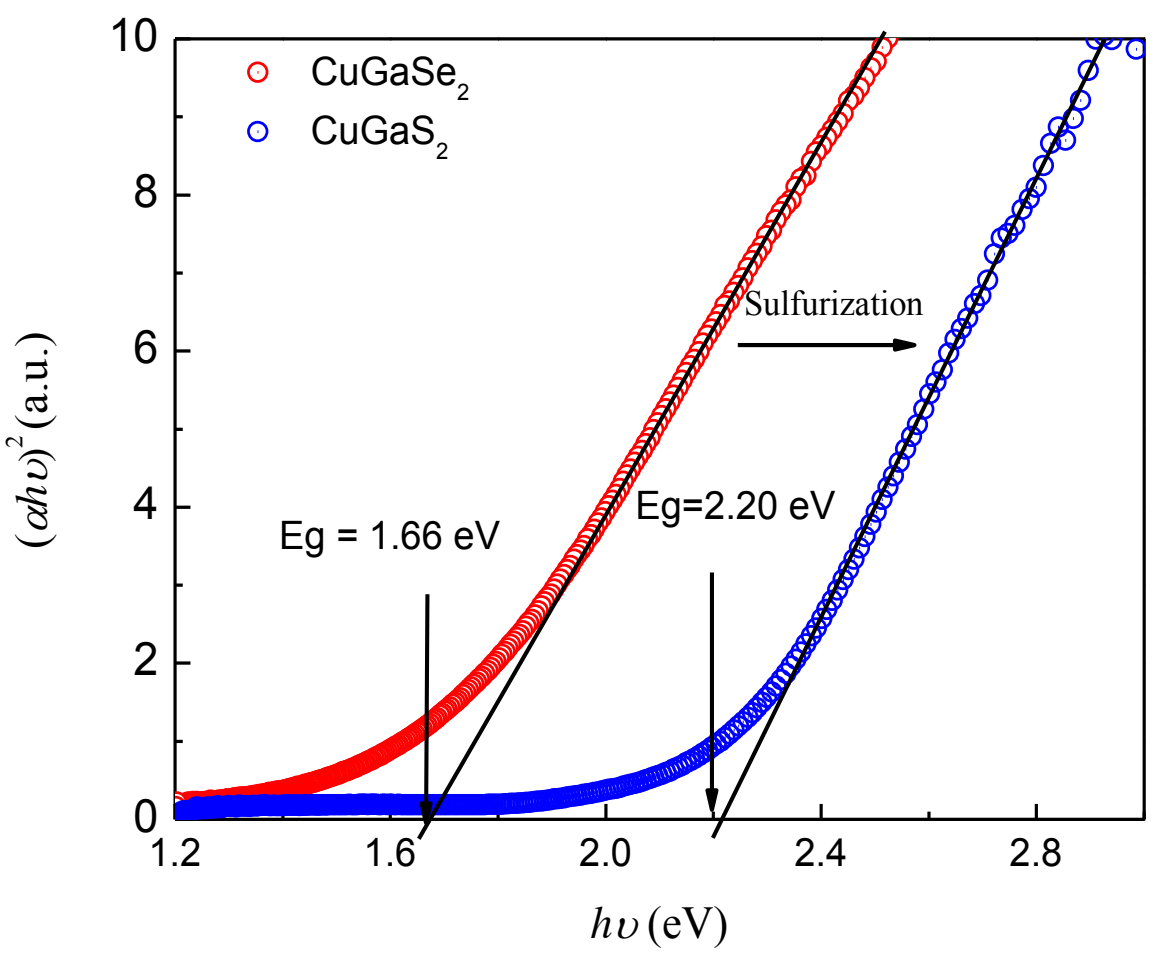

Figure 6. Plot of $(\alpha h v)^{2}$ vs. Photon energy for $\mathrm{CuGaSe}_{2}$ and $\mathrm{CuGaS}_{2}$ thin films.

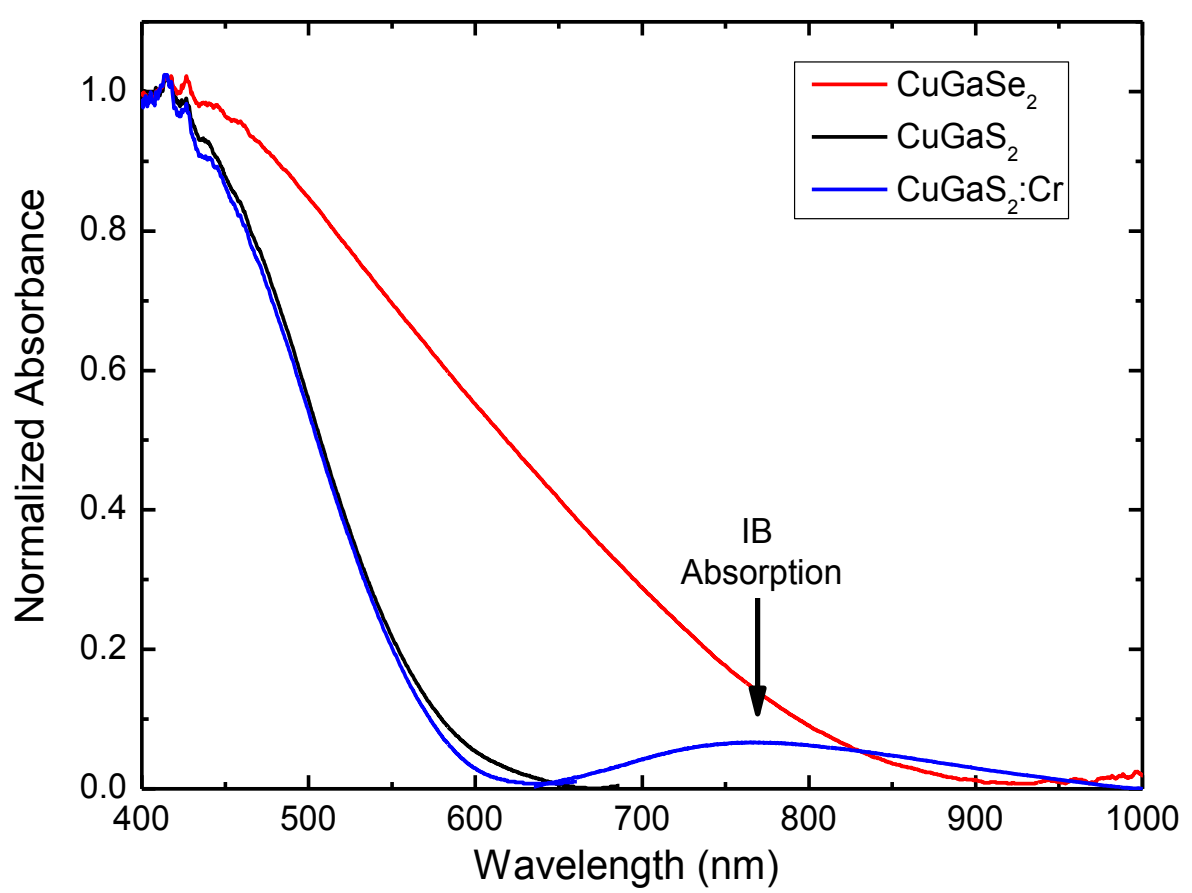

Figure 7. Comparison of the absorbance of $\mathrm{CuGaSe}_{2}, \mathrm{CuGaS}_{2}$ and $\mathrm{CuGaS}_{2}: \mathrm{Cr}$ thin films. The broad absorption band observed for $\mathrm{CuGaS}_{2}: \mathrm{Cr}$, centred at $760 \mathrm{~nm}$ is attributed to Cr-related intermediate band. 


\section{TABLES}

Table I. Calculated values for the crystallite size of $\mathrm{CuGaSe}_{2}$ and $\mathrm{CuGaS}_{2}$ thin films. Uncertainties appear in parentheses.

\begin{tabular}{|c|c|c|c|}
\hline Samples & $\begin{array}{c}2 \theta \text { for }\left(\begin{array}{lll}1 & 1 & 2\end{array}\right) \text { peak } \\
\text { (degree) }\end{array}$ & $\begin{array}{l}\text { FWHM } \\
\text { (degree) }\end{array}$ & $\begin{array}{c}\text { Crystallite size } \\
\text { (nm) }\end{array}$ \\
\hline $\begin{array}{l}\text { (a) As deposited- } \\
\mathrm{CuGaSe}_{2}\end{array}$ & - & - & - \\
\hline $\begin{array}{l}\text { (b) Annealed- } \\
\mathrm{CuGaSe}_{2}\end{array}$ & $27.794(1)$ & $0.20(1)$ & $43(2)$ \\
\hline $\begin{array}{l}\text { (c) Sulphurized- } \\
\mathrm{CuGaS}_{2}\end{array}$ & 29.187 (2) & $0.18(2)$ & $48(4)$ \\
\hline
\end{tabular}

Table II. AFM characterization of $\mathrm{CuGaSe}_{2}$ and $\mathrm{CuGaS}_{2}$ thin films.

\begin{tabular}{|c|c|c|}
\hline Sample id. & Roughness (nm) & Grain size (nm) \\
\hline As deposited $-\mathrm{CuGaSe}_{2}$ & 234 & 160 \\
\hline Annealed $-\mathrm{CuGaSe}_{2}$ & 336 & 334 \\
\hline Sulphurized $-\mathrm{CuGaS}_{2}$ & 422 & 573 \\
\hline
\end{tabular}

Table III. EDS analysis of elemental composition of $\mathrm{CuGaSe}_{2}$ and $\mathrm{CuGaS}_{2}$ films. EDS uncertainties is estimated to be about $1 \%$.

\begin{tabular}{|c|c|c|c|c|c|}
\hline Samples id. & $\% \mathrm{Cu}$ & $\% \mathrm{Ga}$ & $\% \mathrm{Se}$ & $\% \mathrm{~S}$ & $(\mathrm{Se}+\mathrm{S}) /(\mathrm{Cu}+\mathrm{Ga})$ \\
\hline $\begin{array}{c}\text { As deposited }- \\
\mathrm{CuGaSe}_{2}\end{array}$ & 26 & 24 & 50 & -- & 1.00 \\
\hline $\begin{array}{c}\text { Annealed }- \\
\mathrm{CuGaSe}_{2}\end{array}$ & 26 & 22 & 52 & -- & 1.08 \\
\hline $\begin{array}{c}\text { Sulphurized }- \\
\mathrm{CuGaS}\end{array}$ & 26 & 22 & $>1$ & 51.0 & 1.08 \\
\hline
\end{tabular}

